\title{
Risk of acquiring listeriosis from consumption of chicken offal among high risk group
}

\author{
Ga Yarn Wai a, John Yew Huat Tang a, Nadiawati Alias b, Chee Hao Kuan c, Sur Guat Goh ${ }^{d}$, Radu \\ Son e \\ a School of Food Industry, Faculty of Bioresources and Food Industry, Universiti Sultan Zainal Abidin (Besut Campus), 22200 Besut, Terengganu \\ ${ }^{b}$ School of Agriculture and Biotechnology, Faculty of Bioresources and Food Industry, Universiti Sultan Zainal Abidin (Besut Campus), 22200 Besut, \\ Terengganu \\ ' School of Bioscience, Faculty of Health and Medical Sciences, Taylor's University Lakeside Campus, 47500 Subang Jaya, Selangor \\ ${ }^{d}$ Food Division, National Public Health Laboratory, $47000 \mathrm{Sg}$. Buloh, Selangor \\ ${ }^{e}$ Department of Food Science, Faculty of Food Science and Technology, Universiti Putra Malaysia, 43400 Serdang, Selangor
}

* Corresponding author: jyhtang@unisza.edu.my

\section{Article history}

Received 8 Mac 2019

Revised 2 April 2019

Accepted 9 October 2019

Published Online 2 February 2020

\begin{abstract}
Listeria monocytogenes causes mild foodborne infection in healthy adults but serious complication in high risk group such as infant, pregnant women, immunocompromised and elderly. This study aims to estimate the probability of infection based on the survivability of $L$. monocytogenes in chicken offal, particularly chicken liver, gizzard and heart. A total of $20 \mu \mathrm{l}$ of $L$. monocytogenes with inoculum size of $9.02 \log \mathrm{CFU} / \mathrm{ml}$ was spiked on the chicken offal and stored at room temperature $\left(28^{\circ} \mathrm{C}\right)$ for $0,1,3$, and $6 \mathrm{~h}$. This experimental design was aimed to simulate the contaminated chicken offal stored at temperature danger zone. It was found that chicken offal supported the growth of $L$. monocytogenes that it significantly grows at 3 and $6 \mathrm{~h}$ incubation. Risk assessment was performed by combining this result with the data from our previous studies as well as data from government agencies and other studies. Dose-response model was used to estimate the probability of listeria infection per year. Immunocompromised was the highest risk group, followed by pregnant women, elderly and general population with probability of infection per year estimated at $3.78 \times 10^{-3}, 1.76 \times 10^{-4}, 5.68 \times 10^{-8}$ and $5.75 \times 10^{-9}$, respectively. It can be concluded that high risk group requires extra caution in their food consumption in order to prevent listeriosis which can result in serious complication and death.
\end{abstract}

Keywords: Risk assessment, L. monocytogenes, chicken offal, immunocompromised, pregnant women, elderly

(C) 2020 Penerbit UTM Press. All rights reserved

\section{INTRODUCTION}

The genus Listeria includes six different species, $L$. monocytogenes, L. ivanovii, L. innocua, L. welshimeri, L. seegligeri and $L$. grayi. Both $L$. monocytogenes and $L$. ivanovii are pathogenic, but only $L$. monocytogenes is associated with humans and animal illness (Rodríguez-Lázaro et al., 2004). L. monocytogenes has emerged as a foodborne pathogen and implicated with various food ranging from dairy products, fresh produce, meats and seafoods. High risk groups such as pregnant woman, immunocompromised individuals, young children and elderly are normally suffer from serious listeriosis infection through consumption of contaminated foods (EFSA, 2018; Norton and Braden, 2007). Cases of L. monocytogenes are rare as shown in the United States with estimated 0.26 cases per 100,000 individuals for the year of 2013 (Nastasijevic et al., 2017). However, the severity of listeriosis accounted for about $30 \%$ more than other common pathogens which resulted in high hospitalization rates and mortality (Crim et al., 2014). Listeria has also been implicated with outbreaks caused by contaminated ice cream (CDC, 2015a) and cheese (CDC, 2015b) and it caused the highest number of death in Europe in the period of 2008-2012 (EFSA and ECDC, 2014). Recently, $L$. monocytogenes has also implicated with outbreak related to pork products which cause four people hospitalized (CDC, 2018).

Foodborne diseases cause significant social and economic burdens from productivity losses, cost of medical treatment and hospitalization (Jeyaletchumi et al., 2010). Risk analysis is an important model to improve food safety by determining the estimated risk of infection in a particular community exposed to the pathogen (Marvin et al., 2009; Jeyaletchumi et al, 2010). Foodborne illness can occur from poor hygiene practices by food handlers as well as consumer. Those who do not practice proper food handling are potentially transmitted pathogens to food due to cross contamination from food contact surfaces (Soon, 2019). Study shown food handlers were not practicing the food safety knowledge they have acquired (Zanin et al., 2017).

Chicken has been the major source of protein in Malaysia compared to beef, pork, duck and lamb. The per capita consumption of chicken has been steadily increasing from $38.59 \mathrm{~kg}$ in the year 2007 to $50.32 \mathrm{~kg}$ in year 2016 (DVS, 2018). Besides chicken meat, chicken offal also serves an important part of Malaysian food. Our previous studies have shown L. monocytogenes present in both chicken meat and chicken offal at an average of $20 \%$ and $24 \%$, respectively (Goh et al., 2012; Kuan et al., 2013). The results show a significant percentage of chicken meat and chicken offal were contaminated and posed risk of listeriosis 
in a susceptible individual. In the present study, a risk assessment model was developed to determine the risk of acquiring listeriosis based on the survivability of $L$. monocytogenes on chicken offal.

\section{METHODOLOGY}

\section{Statement of purpose}

The goal of this study was to estimate the probability of listeria infection from chicken offal consumption based on the $L$. monocytogenes survivability on chicken offal. The calculation of risk estimate was based on data from this study, previous study (Goh et al., 2014), and assumptions based on the data from other studies and government data. All the assumptions and uncertainties surrounding inputs were clearly stated. Risk assessment model was developed based on hazard identification, hazard characterization, exposure assessment and risk characterization. The probability of listeriosis from chicken offal consumption was calculated.

\section{Hazard identification}

L. monocytogenes can be found in a diverse environment, food products, animals and human (Buchanan et al., 2017). Almost all cases of human listeriosis are foodborne which are contaminated with $L$. monocytogenes (Cossart and Bierne, 2001). Studies have found $L$. monocytogenes present in chicken offal, such liver and gizzard averaging from 26 to 63 (Arumugaswamy et al., 1994; Kuan et al., 2013). Previous risk assessment study concluded that most listeriosis cases happened to the susceptible groups after the consumption of food that supports growth stored at inappropriate temperature for an extended period of time (US FDA/FSIS, 2003). Based on the prevalence study, chicken offal consumption has been reported to pose risk of listeriosis among high risk group (Kuan et al., 2015).

\section{Hazard characterization}

L. monocytogenes is the bacteria species that are predominantly associated with human illnesses such as meningitis, encephalitis, and sepsis (Schlech and Acheson, 2000). Listeriosis normally causes serious complication among susceptible groups from neonates, infants, young children, pregnant women, elderly and immunocompromised patients (Buchanan et al. 2017, Jeyaletchumi et al., 2010). A large number of $L$. monocytogenes ranging from 10 to 100 million of viable cells are required to cause illness in a healthy person. However, a relatively small number of the bacteria $(0.1-10$ million viable cells $)$ is capable of causing illness in high risk groups (Bortolussi, 2008; Tauxe, 2001).

L. monocytogenes infections are generally non-invasive that resulted in mild, febrile illness. The non-invasive infection generally required ingestion of a large number of $L$. monocytogenes cells. Infected individuals will develop "flu-like" symptoms as well as fever and diarrhea (Aureli et al., 2000). However, it can cause invasive listeriosis which resulted in severe symptoms and fatality. The cases of invasive listeriosis were found to be more prevalent among high risk groups (Buchanan et al., 2017). Thus, the current risk assessment focused on invasive listeriosis among high risk groups. Dose-response relations model used to describe dose interaction, infectivity and the probability of infection from the exposure to the L. monocytogenes was adapted from FAO/WHO (2004). In this model, each microbial cell is assumed to have an equal chance of causing infection. Walls (2006) highlighted the need to dose-response model which help to address the need of human being exposed to the hazard in order to calculate the probability.

Dose response model FAO/WHO (2004) used for estimating the probability of listeriosis in the study was as follow:

$\mathrm{P}_{\text {illness }}=1-\exp ^{-\mathrm{r}^{*} \mathrm{~N}}$

where $r$ is a variable that describes the dose/response relationship and $\mathrm{N}$ is the amount of microbes ingested.

This model makes assumption that every ingested pathogen will have equal probability (variable " $r$ ") to cause infection within a particular population. The numbers of L. monocytogenes cells used to calculate the probability of infection among high risk group was around $5 \log$ CFU per serving based on the average dose capable of causing illness in high risk groups (Bortolussi, 2008; Tauxe, 2001). This model predicts the likelihood of getting foodborne illness based on the amount of pathogens ingested. Thus, the likelihood of listeriosis will remain the same regardless of the amount of cells ingested once the infective dose is achieved. The dose-response relationship values for different high risk group were summarized in Table 1 .

Table 1 Dose-response relationship for $L$. monocytogenes for different high-risk groups

\begin{tabular}{lll}
\hline \multicolumn{1}{c}{ Group } & \multicolumn{1}{c}{$\begin{array}{c}\text { Dose- } \\
\text { response } \\
\text { relationship } \\
\text { r-value }\end{array}$} & \multicolumn{1}{c}{ Reference } \\
\hline General population & $8.5 \times 10^{-16}$ & FAO/WHO (2004) \\
Immunocompromised & $5.6 \times 10^{-10}$ & $\begin{array}{l}\text { Lindqvist and } \\
\text { Westwoo (2000) }\end{array}$ \\
$\begin{array}{l}\text { Pregnant women } \\
\begin{array}{l}\text { Elderly, above } 60 \\
\text { years of age }\end{array}\end{array}$ & $2.6 \times 10^{-11}$ & FDA/FSIS (2003) \\
\hline
\end{tabular}

It was assumed that there were no seasonality and consumption pattern changes throughout the year (52 weeks). The probability of illness per year was calculated based on the formula below (Robertson et al., 2005):

Probability of illness per year $=1-\left(1-\mathrm{P}_{\text {inf }} \text { per individual }\right)^{52}$

\section{Exposure assessment}

Exposure assessment requires data such as prevalence or concentration of microbes found in a specific food per serving (Walls, 2006). The exposure assessments for estimating the risk of $L$. monocytogenes infection were based on the survivability of $L$. monocytogenes on chicken liver, gizzard and heart performed in this study with reference to the previous study on the transmission of the bacteria from raw to cooked samples after contact with food contact surfaces (Goh et al., 2014).

Survivability of L. monocytogenes on chicken liver, gizzard and heart

L. monocytogenes growth on chicken liver, gizzard and heart were determined to simulate its survival patterns in cases of crosscontamination due to poor food handling. The level of $L$. monocytogenes on chicken offal will affect the amount being transfer to the cooked chicken offal via food contact surfaces (Goh et al., 2014).

\section{- Preparation of L. monocytogenes inoculum}

L. monocytogenes ATCC 7944 was revived in $10 \mathrm{ml}$ of Tryptic Soy Broth (TSB) (Merck, Germany) and incubated at $37^{\circ} \mathrm{C}$ for $24 \mathrm{~h}$. The revived culture was streaked on PALCAM agar (Merck, Germany) and incubated at $37^{\circ} \mathrm{C}$ for $24 \mathrm{~h}$ to obtain a purified culture. Pure $L$. monocytogenes culture was grown in TSB (Merck) in a condition described earlier before the culture was harvested for inoculum preparation. The inoculum of $L$. monocytogenes was determined using spectrophometer at $600 \mathrm{~nm}$ wavelength to give OD 0.99 which corresponds to $9.20 \log \mathrm{CFU} / \mathrm{ml}$.

\section{- Survival determination of L. monocytogenes on chicken offal}

The survival determination study was carried out as described in our previous study with modification (Tang et al., 2014). Three grams of chicken liver, gizzard and heart were placed in universal bottles meant for different holding time $(0,1,3$, and $6 \mathrm{~h})$. A total of $20 \mu \mathrm{l}$ of inoculum was spiked onto the chicken offal and incubated at $28^{\circ} \mathrm{C}$. $L$. monocytogenes enumeration was performed using a spread plate method on PALCAM agar (Merck, Germany). The experiments were done in triplicates. 


\section{- Data analysis}

Data collected during the experiment was analyzed using SPSS 17.0 software. The data were analyzed using oneway ANOVA. The significance level was set at $\mathrm{p}<0.05$.

Transfer of L. monocytogenes to cooked sample

The transfer data of L. monocytogenes from raw to cooked sample was obtained from our previous study (Goh et al., 2014). Poor food handling which let to contaminated food has been recognized as one of the main factors which lead to the foodborne illness or outbreak (Soon, 2019). Goh et al. (2014) reported the transfer rate of $L$. monocytogenes to cooked sample ranging from 0 to $87 \%$ depending on the type of cutting boards and conditions of the cooked samples (hot or cooled) An average of $44 \%$ was used in this study to cover all the possible scenarios. The serving size of chicken offal consumption in Malaysia was based on data reported by Kuan et al. (2015) at 125 g per week.

\section{Population of the high-risk groups}

Based on the Malaysia population in year 2018 (Department of Statistics Malaysia, 2019), it was estimated 127, 900 live births as of the year 2018 and it was assumed that each live birth was from one pregnant woman (Department of Statistics Malaysia, 2019). Thus, it was assumed there were 127, 900 pregnant women as of year 2018. Due to no data available for immunocompromised population in Malaysia, it is assumed $3.6 \%$ of the total population are immunocompromised which give around 1.2 million people fall within this group based on the estimation made by Laura (2008). Table 2 shows the population for each high- risk group in Malaysia.

Table 2 Population of high- risk groups in Malaysia.

\begin{tabular}{|c|c|c|c|}
\hline Group & Year & $\begin{array}{l}\text { Number } \\
\text { of people }\end{array}$ & Reference \\
\hline $\begin{array}{l}\text { Total } \\
\text { population }\end{array}$ & 2018 & $\begin{array}{l}32,600,00 \\
0\end{array}$ & $\begin{array}{l}\text { Department of Statistics } \\
\text { Malaysia (2019) }\end{array}$ \\
\hline $\begin{array}{l}\text { Immuno- } \\
\text { compromised }\end{array}$ & NA & $1,200,000$ & Laura (2008) \\
\hline $\begin{array}{l}\text { Pregnant } \\
\text { women }\end{array}$ & 2018 & ${ }^{\mathrm{a}} 127,900$ & $\begin{array}{l}\text { Department of Statistics } \\
\text { Malaysia (2019) }\end{array}$ \\
\hline $\begin{array}{l}\text { Elderly, } \\
\text { above }\end{array}$ & 2020 & b2,347,200 & $\begin{array}{l}\text { Department of Statistics } \\
\text { Malaysia (2006) }\end{array}$ \\
\hline
\end{tabular}

It was assumed $3.6 \%$ of the total population are immunocompromised based on assumption made by Laura (2008).

${ }^{b}$ It was projected $7.2 \%$ of the total population are elderly based on the projection made by Department of Statistics Malaysia (2006).

\section{RESULTS AND DISCUSSION}

The growth of L. monocytogenes on chicken offal stored at room temperature $\left(28^{\circ} \mathrm{C}\right)$ over $6 \mathrm{~h}$ period was summarized in Table 3. $L$. monocytogenes were found to grow significantly in chicken liver, gizzard and heart at 3 and 6 hours. There was no significant difference at $1 \mathrm{~h}$. The survival pattern of $L$. monocytogenes was similar among chicken liver, gizzard and heart. The amount of L. monocytogenes at cooked chicken offal was calculated based on the average bacteria level at $6 \mathrm{~h}$ and transfer rate of $44 \%$ which corresponds to $3.02 \mathrm{log} \mathrm{CFU} / \mathrm{g}$ or $1.04 \times 10^{3} \mathrm{CFU} / \mathrm{g}$.

The calculated amount of L. monocytogenes $\left(1.04 \times 10^{3} \mathrm{CFU} / \mathrm{g}\right)$ was used to calculate the probability of infection as shown in Table 4 Based on the dose-response model (FAO/WHO, 2004), it was found the immunocompromised group has the highest probability of infection per year at $3.78 \times 10^{-3}$ cases. This is followed by pregnant women 1.76 x $10^{-4}$, elderly $5.68 \times 10^{-8}$ and general population $5.75 \times 10^{-9}$.

It is generally recognized that L. monocytogenes is capable of growing at chilled or refrigerator temperature (Omac, Moreira and Castell-Perez, 2018; Millilo et al., 2012). L. monocytogenes was found to grow on chicken liver, gizzard and heart after $3 \mathrm{~h}$ storage at room temperature $\left(28^{\circ} \mathrm{C}\right)$ even though it is known to be psychophilic bacteria. The finding is line with other studies that $L$. monocytogenes was capable of growing in various food stored at $25^{\circ} \mathrm{C}$. L. monocytogenes was reported to grow $4-6 \log \mathrm{CFU} / \mathrm{g}$ on celery and chicken salad stored at $25^{\circ} \mathrm{C}$ over 4 days period (Sahu et al., 2017). Studies have found significant $L$. monocytogenes contamination in chicken offal (Arumugaswamy et al., 1994; Kuan et al., 2013). Thus, the growth of L. monocytogenes on chicken offal at room temperature will increase the risk of cross contamination in the kitchen environment. Storage of chicken offal at temperature danger zone or under cooking may allow L. monocytogenes to survive and increase in number (Lin et al., 2004).

Table 3 Growth of Listeria monocytogenes on chicken liver, gizzard and heart over $6 \mathrm{~h}$ incubation at room temperature.

\begin{tabular}{|c|c|c|c|c|}
\hline \multirow{2}{*}{ Samples } & \multicolumn{4}{|c|}{ Level of Listeria monocytogenes (log CFU/g) } \\
\hline & $\mathrm{Oh}$ & $1 \mathrm{~h}$ & $3 \mathbf{h}$ & $6 \mathrm{~h}$ \\
\hline Liver & $\begin{array}{l}6.08 \pm \\
0.19^{\mathrm{a}, \mathrm{A}}\end{array}$ & $\begin{array}{l}6.24 \pm \frac{ \pm}{a, A} \\
0.06^{a}\end{array}$ & $\begin{array}{l}6.61 \frac{t}{\mathrm{~b}, \mathrm{~A}} \\
0.18^{-1}\end{array}$ & $\begin{array}{l}7.16 \pm \frac{ \pm}{c, A} \\
0.08^{c, A}\end{array}$ \\
\hline Gizzard & 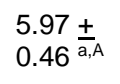 & $\begin{array}{l}6.17 \stackrel{ \pm}{ \pm, A} \\
0.37^{a, A}\end{array}$ & $\begin{array}{l}6.44^{ \pm}+\frac{}{b, A} \\
0.16^{b, A}\end{array}$ & $\begin{array}{l}7.23 \underset{ \pm}{ \pm}, \mathrm{A} \\
0.48^{\mathrm{c}, \mathrm{A}}\end{array}$ \\
\hline Heart & $\begin{array}{l}5.21 \pm \\
0.04\end{array}$ & $\begin{array}{l}5.31 \pm \\
0.08^{\mathrm{a}, \mathrm{B}}\end{array}$ & $\begin{array}{l}5.56+\frac{+}{\mathrm{b}, \mathrm{B}} \\
0.0{ }^{2}\end{array}$ & $\begin{array}{l}6.18 \pm \\
0.07 \mathrm{c}, \mathrm{B}\end{array}$ \\
\hline
\end{tabular}

Data represent mean \pm standard deviation of three replications.

$\mathrm{a}, \mathrm{b}, \mathrm{c}$ Data in the same row with different letters is different significantly $(\mathrm{p}<0.05)$.

$\mathrm{A}, \mathrm{B}, \mathrm{C}$ Data in the same column with different letters is different significantly $(\mathrm{p}<0.05)$.

Table 4 Risk assessment of Listeria monocytogenes in chicken offal consumption by high risk groups in Malaysia.

\begin{tabular}{lcccc}
\hline & $\begin{array}{c}\text { General } \\
\text { population }\end{array}$ & $\begin{array}{c}\text { Immuno- } \\
\text { compromised }\end{array}$ & $\begin{array}{c}\text { Pregnant } \\
\text { women }\end{array}$ & $\begin{array}{c}\text { Elde } \\
\text { rly }\end{array}$ \\
\hline $\begin{array}{l}\text { Concentration } \\
\text { Mean of } L \text {. }\end{array}$ & $1.04 \times 10^{3}$ & $1.04 \times 10^{3}$ & $1.04 \times 10^{3}$ & 1.04 \\
$\begin{array}{l}\text { monocytogenes } \\
\text { (CFU/g) }\end{array}$ & & & & $\times$ \\
& & & & \\
Dose & & & & \\
Serving size (g) & 125 & 125 & 125 & 125 \\
Dose (log & $1.30 \times 10^{5}$ & $1.30 \times 10^{5}$ & $1.30 \times 10^{5}$ & 1.30 \\
CFU/serving) & & & & $\times$ \\
& & & & $10^{5}$
\end{tabular}

\begin{tabular}{|c|c|c|c|c|}
\hline \multicolumn{5}{|c|}{ Probability of infection per serving } \\
\hline r-value & $8.5 \times 10^{-16}$ & $5.6 \times 10^{-10}$ & $2.6 \times 10^{-11}$ & $\begin{array}{l}8.4 \times \\
10^{-15}\end{array}$ \\
\hline $\begin{array}{l}\text { Probability of } \\
\text { infection per } \\
\text { serving }\end{array}$ & $\underset{10}{1.11 \times 10^{-}}$ & $7.28 \times 10^{-5}$ & $3.38 \times 10^{-6}$ & $\begin{array}{c}1.09 \\
\times 10^{-} \\
9\end{array}$ \\
\hline
\end{tabular}

Probability of listeriosis cases per 100,000 population

$\begin{array}{lcccc}\text { Population } & 32,600,00 & 1,200,000 & 127,900 & 2,34 \\ & 0 & & & 7,20 \\ & & & & 0 \\ \text { Probability per } & 2.87 \times 10^{-4} & 188.92 & 8.79 & 2.84 \\ 100000 & & & & \times 10 \\ \text { population } & & & & 3\end{array}$

\begin{tabular}{lcccc}
$\begin{array}{l}\text { Probability of infection per year } \\
\text { Number of }\end{array}$ & 52 & 52 & 52 & 52 \\
$\begin{array}{l}\text { servings } \\
\begin{array}{l}\text { Probability of } \\
\text { infection per }\end{array}\end{array}$ & $5.75 \times 10^{-9}$ & $3.78 \times 10^{-3}$ & $1.76 \times 10^{-4}$ & 5.68 \\
year & & & & $\begin{array}{c}510^{-} \\
8\end{array}$ \\
\hline
\end{tabular}

Chicken offal is not generally consumed raw but chicken liver tend to be undercooked in order to retain its juiciness. Undercooking and contamination due to poor handling practices will contribute to the risk of listeriosis among high risk groups. Poor food preparation practices have been identified as the contributing factor to these contamination (Soon, 2019). 
Immunocompromised patients cover a variety of diseases that affect different components of the immune system. Immunocompromised patients can be categorized into congenital and acquired immunodeficiencies with the former is primary immunodeficiency diseases (PIDs) and the later cover range of disease from HIV/AIDs, cancers, hematologic and lymphatic malignancy, and others. Infection has been recognized as the main factor causing illness and death that required medical treatment (Meidani et al., 2014). From the risk estimates, it was found that this group is the most high risk group to get listeriosis. As such, this population group requires more vigilant in the selection of the uncontaminated food for consumption as low number of L. monocytogenes might cause serious illness. Brain infection cases due to L. monocytogenes has been reported in multiple sclerosis and stem cell transplant patients (Barocci et al., 2015; Tecellioglu et al., 2019).

Listeriosis is recognized as the most dangerous bacteria that cause death for fetuses and infants (Xu et al., 2017). A study reported women experiencing down-regulation of the immune system during pregnancy due to hormonal changes. Such changes increase the risk of foodborne illness among pregnant women (Smith, 1999). Pregnant women are generally 20 times greater risk of acquiring listeriosis than general population (Cook et al., 2018). Listeriosis can cause serious complication during pregnancy such as miscarriage, stillbirth, preterm labor, or death to the newborn (Xu et al., 2017). Listeriosis during pregnancy frequently occurs during the third trimester of pregnancy (Cook et al., 2018). This study found pregnant women were of higher risk of acquiring listeriosis than the elderly group was in agreement with a study done by Silk et al. (2012).

This risk assessment study proved high risk group should pay extra attention to this foodborne pathogen which can cause serious illness or even death. The incidence of listeriosis might be underreported due to mild clinical symptoms such as flulike fever and diarrhea. Microbiological examination was rarely performed for mild clinical symptoms and early pregnancy loses are generally not being investigated microbiologically (McLauchilin et al., 2004).

\section{CONCLUSION}

L. monocytogenes ability to grow in chicken offal stored at room temperature posed a significant risk of foodborne illness from inadequate cooking or contamination of cooked food. An immunocompromised group has the highest risk of listeriosis followed by pregnant women, elderly and general population. Risk assessment study based on the data from multiple sources from farm to table is important to provide information on the probability of illness resulted from contaminated food consumption by the high risk groups.

\section{ACKNOWLEDGEMENT}

The authors would like to thank the fund provider International Foundation of Sciences, Sweden (E/5237-2F). Special thanks to Universiti Putra Malaysia and Universiti Sultan Zainal Abidin, Malaysia for providing the facilities.

\section{REFERENCES}

Arumugaswamy, R. K., Rahmat Ali, G. R., Hamid, S. N. 1994. Prevalence of Listeria monocytogenes in foods in Malaysia. International Journal of Food Microbiology 23, 117-121.

Aureli, P., Fiorucci, G. C., Caroli, D., Marchiaro, B., Novara, O., Leone, L., Salmoso, S. 2000. An outbreak of febrile gastroenteritis associated with corn contaminated by Listeria monocytogenes. New England Journal of Medicine 342, 1236-1241.

Barocci, S., Mancini, A., Canovari, B., Petrelli, E., Sbriscia-Fioretti, E., Licci A., D'Addesa, S., Petrini, G., Giacomini, M., Renzi, A., Migali, A., and Briscolini, S. 2015. Listeria monocytogenes meningitis in an immunocompromised patient. New Microbiologica 38(1), 113-118.

Bortolussi, R. 2008. Listeriosis: A Primer. Canadian Medical Association Journal 179(8), 795-797.

Buchanan, R. L., Gorris, L. G. M., Hayman, M. M., Jackson, T. C., Whiting, R. C. 2017. A review of Listeria monocytogenes: An update on outbreaks, virulence, dose-response, ecology, and risk assessments. Food Control 75, $1-13$.

CDC (Centers for Disease Control and Prevention). 2015a. Multistate Outbreak of Listeriosis Linked to Blue Bell Creameries Products. http://www.cdc.gov/listeria/outbreaks/ice-cream-03-15 Accessed on 15 January 2019

CDC (Centers for Disease Control and Prevention). 2015b. Multistate Outbreak of Listeriosis Linked to Soft Cheeses (Final Update). http://www.cdc.gov/listeria/outbreaks/soft-cheeses-09-15/index.html Accessed on 15 January 2019

CDC (Centers for Disease Control and Prevention). 2018. Outbreak of Listeria linked to pork products. https://www.cdc.gov/listeria/outbreaks/porkproducts-11-18/index.html Assessed on 15 January 2019

Cook, J. L., Graves, L., Kirkham, C. 2018. Listeriosis in pregnancy: Practitioners' food safety counselling practices to pregnant women. Journal of Obstetrics and Gynaecology Canada 40(9), 1139-1147.

Cossart, P., Bierne, H. 2001. The use of host cell machinery in the pathogenesis of Listeria monocytogenes. Current Opinion in Immunology 13(1), 96103.

Crim, S. M., Iwamoto, M., Huang, J. Y., Griffin, P. M., Gilliss, D., Cronquist, A. B. et al. 2014. Incidence and trends of infection with pathogens transmitted commonly through food. Foodborne Diseases Active Surveillance Network, 10 U.S. sites, 2006- 2013. Morbidity and Mortality Weekly Report 63(15), 328-32.

Department of Statistics Malaysia. 2016. Population projection (revised), Malaysia, 2010 2040 . https://www.dosm.gov.my/v1/index.php?r=column/cthemeByCat\&cat=11 8\&bul_id=Y3kwU2tSNVFDOWp1YmtZYnhUeVBEdz09\&menu_id=L0p heU43NWJwRWVSZklWdzQ4TlhUUT09 Assessed on 15 February 2019.

Department of Statistics Malaysia. 2019. Population and Demography. https://www.dosm.gov.my/v1/index.php?r=column/ctwoByCat\&parent_id =115\&menu_id=L0pheU43NWJwRWVSZklWdzQ4TlhUUT09 Assessed on 15 February 2019.

DVS (Department of Veterinary Services). 2018. Malaysia: Per Capita Consumption of Livestock Products, 2007-2016. http://www.dvs.gov.my/dvs/resources/user_1/DVS\%20pdf/Perangkaan\%2 02015\%202016/page_10.pdf Assessed on 15 January 2019

EFSA (European Food Safety Authority) and ECDC (European Centre for Disease Prevention and Control). 2014. The European Union summary report on trends and sources of zoonoses, zoonotic agents and foodborne outbreaks in 2012. EFSA Journal 12 (2): 3547. http://www.efsa.europa.eu/en/efsajournal/doc/3547.pdf Assessed on 15 January 2019

EFSA (European Food Safety Authority). 2018. Listeria infection increases in vulnerable groups. https://www.efsa.europa.eu/en/press/news/180124 Assessed on 15 January 2019

FAO/WHO. 2004. Risk assessment of Listeria monocytogenes in ready-to-eat foods. Technical Report. http://www.fao.org/3/a-y5394e.pdf Assessed on 15 February 2019.

FDA/FSIS. 2003. Quantitative assessment of the relative risk to public health from foodborne Listeria monocytogenes among selected categories of ready-to-eat

foods. https://www.fda.gov/downloads/Food/FoodScienceResearch/UCM197330 .pdf Assessed on 15 February 2019.

Goh, S. G., Kuan, C. H., Loo, Y. Y., Chang, W. S., Soopna, P., Tang, J. Y. H., Nakaguchi, Y., Nishibuchi, M., Afsah-Hejri, L., Son R. 2012. Listeria monocytogenes in retailed raw chicken meat in Malaysia. Poultry Science 91, 2686-2690.

Goh, S. G., Afsah-Hejri, L., Kuan, C. H., Loo, Y. Y., Lye, Y. L., Chang, W. S., Soopna, P., Shahril, N., Tang, J. Y. H., Yaya, R., Nakaguchi, Y., Nishibuchi, M., Son R. 2014. Transmission of Listeria monocytogenes from raw chicken meat to cooked chicken meat through cutting boards. Food Control 37, 5155.

Jeyaletchumi, P., Tunung, R., Margaret, S. P., Chai, L. C., Son, R., Farinazleen, M. G., Cheah, Y. K., Nishibuchi, M., Nakaguchi, Y., Pradeep, K. M. 2010. Assessing the risk of acquiring listeriosis from consumption of minimally processed vegetables using a step-wise risk assessment. Asian Journal of Food and Agro-Industry 3(6), 587-596.

Kuan, C. H., Goh, S.G., Loo, Y. Y., Chang, W. S., Puspanadan, S., Tang, J. Y. H., Nakaguchi, Y., Nishibuchi, M., Mahyudin, N. A., Radu, S. 2013. Prevalence and quantification of Listeria monocytogenes in chicken offal at the retail level in Malaysia. Poultry Science 92(6), 1664-1669.

Kuan, C. H., Goh, S.G., Loo, Y. Y., Chang, W. S., Lye, Y. L., Puspanadan, S., Tang, J. Y. H., Mahyudin, N. A., Nishibuchi, M., Nakaguchi, Y., Son, R. 2015. Risk assessment of acquiring listeriosis from consumption of chicken offal in Selangor, Malaysia. International Food Research Journal 22(4), 1711-1718. 
Laura, H. K. 2008. The growing number of immunocompromised. Bulletin of the Atomic Scientists. https://thebulletin.org/2008/01/the-growing-numberof-immunocompromised/ Accessed on 15 February 2019.

Lin, Y. T., Labbe, R. G., Shetty, K. 2004. Inhibition of Listeria monocytogenes in fish and meat systems using oregano and cranberry synergies. Applied and Environmental Microbiology 70, 5672-5678.

Lindqvist, R., Westoo, A. (2000). Quantitative risk assessment for Listeria monocytogenes in smoked or gravid salmon and rainbow trout in Sweden. International Journal of Food Microbiology 58, 181-196.

Marvin, H. J. P., Kleter, G. A., Frewer, L. J., Cope, S., Wentholt, M. T. A. and Rowe, G. 2009. A working procedure for identifying emerging food safety issues at an early stage: Implications for European and international risk management practices. Food Control 20, 345-356.

McLauchilin, J., Mitchell, R. T., Smerdon, W. J., and Jewell, K. 2004. Listeria monocytogenes and listeriosis: a review of hazard characterization for use in microbiological risk assessment of foods. International Journal of Food Microbiology 92, 15-33.

Meidani, M., Naeini, A. E., Rostami, M., Sherkat, R., and Tayeri, K. 2014 Immunocompromised patients: Review of the most common infections happened in 446 hospitalized patients. Journal of Research in Medical Sciences 19(Supp 1), S71-S73.

Milillo, S. R., Friedly, E. C., Saldivar, J. C., Muthaiyan, A., O'bryan, C., Crandall, P. G., Johnson, M. G., Ricke, S. C. 2012. A review of the ecology, genomics, and stress response of Listeria innocua and Listeria monocytogenes. Critical Review in Food Science and Nutrition 52 (8), 712 725 .

Nastasijevic, I., Milanov, D., Velebit, B., Djordjevic, V., Swift, C., Painset, A., Lakicevic, B. 2017. Tracking of Listeria monocytogenes in meat establishment using Whole Genome Sequencing as a food safety management tool: A proof of concept. International Journal Food Microbiology 257, 157-164

Norton, D. M., Braden, C. R. 2007. Foodborne listeriosis. In E. T. Ryser, \& E. H. Marth (Eds.), Listeria, listeriosis, and food safety. New York: CRC Press. 305-356.

Omac, B., Moreira, R. G., Castell-Perez, E. 2018. Quantifying growth of coldadapted Listeria monocytogenes and Listeria innocua on fresh spinach leaves at refrigeration temperatures. Journal of Food Engineering 224, 17 26.

Robertson, L. J., Greig, J. D., Gjerde, B., Fazil, A. 2005. The potential for acquiring cryptosporidiosis or giardiasis from consumption of mung bean sprouts in Norway: a preliminary step-wise risk assessment. International Journal of Food Microbiology 98, 291-300.

Rodríguez-Lázaro, D., Hernández, M., Pla, M. 2004. Simultaneous quantitative detection of Listeria spp. and Listeria monocytogenes using a duplex realtime PCR-based assay. FEMS Microbiology Letters 233, 257-267.
Sahu, S. N., Kim, B., Ferguson, M. S., Zink, D. L., Datta, A. R. 2017. Growth potential of Listeria monocytogenes in artificially contaminated celery and chicken salad. Food Control 73, 1229-1236.

Schlech, W. F. III, Acheson, D. 2000. Foodborne listeriosis. Clinical Infectious Disease 31(3), 770-775.

Silk, B. J., Date, K. A., Jackson, K. A., Pouillot, R., Holt, K. G., Graves, L. M., et al. 2012. Invasive listeriosis in the Foodborne Diseases Active Surveillance Network (FoodNet), 2004-2009: Further targeted prevention needed for higher-risk groups. Clinical Infectious Diseases 54(suppl. 5), S396-S404.

Smith, J. L. 1999. Foodborne infections during pregnancy. Journal of Food Protection 62, 818-829.

Soon, J. M. 2019. Finger licking good? An observational study of hand hygiene practices of fast food restaurant employees and consumers. British Food Journal https://doi.org/10.1108/BFJ-07-2018-0420

Tang, J. Y. H., Mohd-Noor, N. H., Mazlan, N., Yeo, C. C., Abu-Bakar, C. A., and Radu, S. 2014. Survival of Vibrio cholerae O1 and Vibrio parahaemolyticus in fried and boiled Malaysian fish sausage. Food Control 41, 102-105.

Tauxe. R. V. 2001. Food Safety and Irradiation: Protecting the Public from Foodborne Infections. Emerging Infectious Diseases 7(3), 516-521.

Tecellioglu, M., Kamisli, O., Kamisli, S., Erdogmus, U. A., and Özcan, C. 2019. Listeria monocytogenes rhombencephalitis in a patient with multiple sclerosis during fingolimod therapy. Multiple Sclerosis and Related Disorders 27, 409-411.

U. S. Department of Health and Human Services, Center for Food Safety and Applied Nutrition, Food and Drug Administration and U.S. Department of Agriculture Food Safety and Inspection Service (U.S. FDA/FSIS). (2003). Quantitative assessment of relative risk to public health from foodborne Listeria monocytogenes among selected categories of ready-to-eat foods. http:// www.fda.gov/downloads/Food/FoodScienceResearch/UCM197330.pdf Accessed 10 February 2019

Walls, I. 2006. Role of quantitative risk assessment and food safety objectives in managing Listeria monocytogenes on ready-to-eat meats. Meat Science 74, 66-75.

Xu, W., Cater, M., Gaitan, A., Drewery, M., Gravois, R., Lammi-Keefe, C. J. 2017. Awareness of Listeria and high-risk food consumption behavior among pregnant women in Louisiana. Food Control 76, 62-65.

Zanin, L. M., de Cunham, D. T., de Rosso, V. V., Capriles, V. D., Stedefeldt, E. 2017. "Knowledge, attitudes and practices of food handlers in food safety: an integrative review", Food Research International 100(1), 53-62. 